Historic, Archive Document

Do not assume content reflects current scientific knowledge, policies, or practices. 


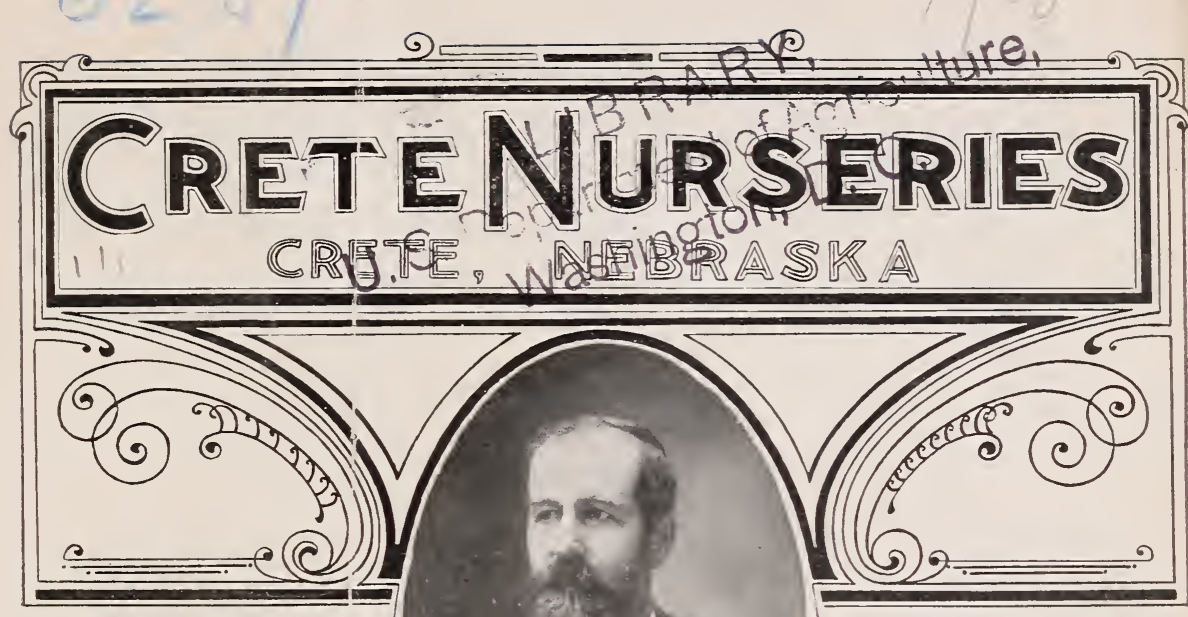

Established in

Nebraska 1872

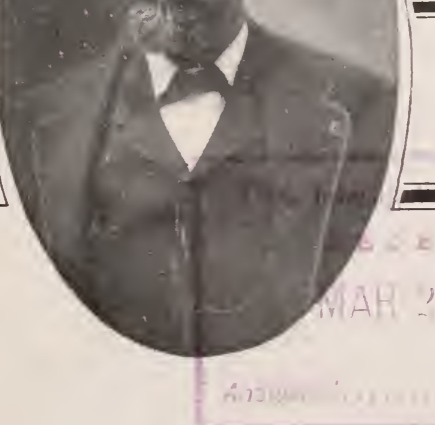

Thirty-six Years in Horticulture

\section{Price List of Choice Grades of Nursery Stock}

The writer came to Nebraska in October, 1871, with the fixed purpose of engaging in commercial orcharding. While waiting for the orchards to attain bearing age, it seemed natural to engage in nursery work. Once entered upon this absorbing line of study, I have not found a stopping place.

The orchards lave expanded from the eighty acres growing on the old farm by the addition of 50,000 additional trees in branch partnership orchards, extending from the eastern portion of Nebraska out through central Nebraska and up to within one mile of the Wyoming line.

\section{A STARTER}

With such intense interest did I enter upon a study of the particular methods necessary for success in Nebraska that the second season of my nursery experience saw me commissioned by the Burlington \& Missouri railroad to raise, plant, and cultivate 750,000 forest trees along the north side of cuts to serve as snow breaks. 


\section{THE BUSINESS GREW}

The publicity attendant upon the success of this, my first contract, caused the business to increase so rapidly that we moved to Crete, establishing the office, packing shed, root cellar, delivery grounds, and small fruit plantations within reach of quick express and freight service.

A tract of two hundred and forty acres near town was rented for a long term of years to provide space for raising trees.

\section{THIRTEEN MILLIONS OF TREES}

During the operations of the timber claim law the Nursery raised and sold thirteen and one-half millions of forest trees in one season; a number sufficient to plant fifty rows of shade trees, eight feet apart in the row, across the state of Nebraska.

\section{OLDEST NURSERY BUSINESS IN NEBRASKA}

Years went by and the other firms which had been in business when we began, dissontinued or moved away. We now have the oldest nursery business in the state.

\section{SATISFACTORY RESULTS}

Seven hundred bushels of cherries was the abundant harvest of one season. The apple trees produced ten thousand bushels in a single crop; while the banner apple crop was THIRTEEN THOUSAND BUSHELS. The orchard returns of those two years were $\$ 6,500.00$ and $\$ 7,000.00$ respectively. The home orchard produced 3,500 bushels in the unfavorable year of 1907 .

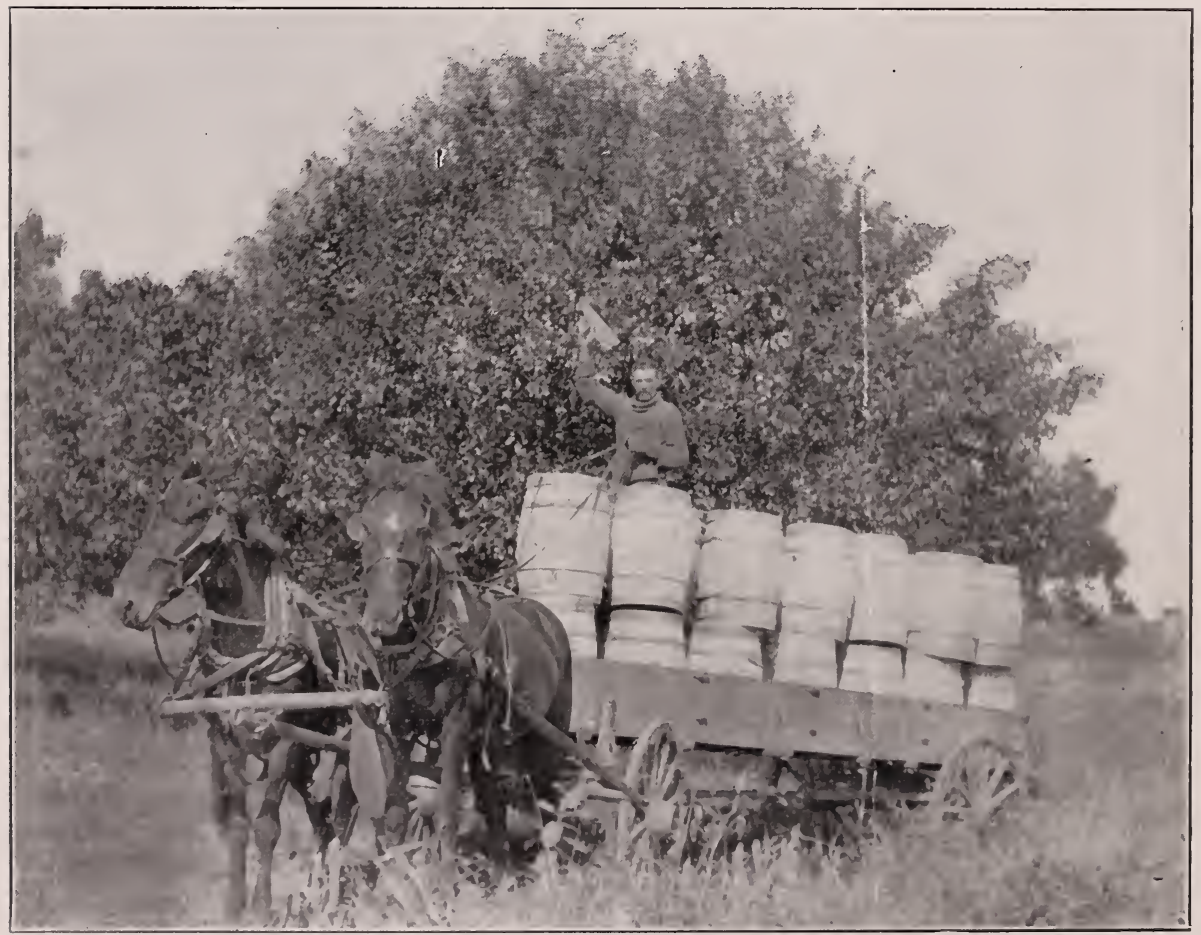




\section{REJOICE AND GROW FRUIT}

The fruit belt is still moving westward. Fine, healthy orchards in western Nebraska are producing fruit that is a revelation. The branch orchard of David Hunter, at sutherland, 317 miles west of Omaha, planted with Crete Nursery trees, has yielded five crops of peaches, cherries, plums and apples, and this last season of 1907 had 2,000 bushels of apples; also cherries and peaches.

The Ed Scriven orchard in Scot's Bluff county, twenty miles from the IVyoming line, supplied by Crete Nurseries, has borne fruit each season since the trees were four years old. This orchard rarely fails to give an abundant supply of fruit for family use and a surplus for sale.

Of 2,400 trees planted in one orchard in Custer county for which we selected the varieties but twenty-seven were lost. These are but three of the thousands of bearing orchards we have supplied in all parts of the West.

\section{THE THREE ESSENTIALS}

Not from theory, but from actual fruiting of our trees in all parts of Nebraska, some of them under the most adverse conditions, we have come to believe that any man can raise fruit if he begins with-

1st-Carefully Grown Trees.

2d-Hardy Varieties Adapted to His Locality.

3d-Good Care.

and follows with-

Taking these points in inverse order,

\section{DON'T ORDER FROM US}

unless you intend to give your trees good care. Neglect kills more trees than any other cause. The results disappoint you, and do not increase our trade. Frankly, we do not seek the trade of the careless planter.

\section{A STARVING HORSE}

is a no more pitiful sight than a tree dying for lack of care. Every tree, bush and shrub in this aatalogue is the result of thoughtful study and careful culture.

We have done our part. We urge you to do yours.

\section{A PRACTICAL SCHOOL OF HORTICULTURE}

Twenty-one years ago we engaged in planting timber claims on four year warranted contracts. We assumed all the expense, risk and care incident to growing the trees, and enabled our patrons to secure patents on the land. We had 2,500 acres under cultivation at one time. We also planted contract orchards for tarmers, doing all the work for three years

The experience we gained wrs invaluable. We thoroughly learned Nebraska's peciliar requirements in every locality from east to west and from north to south. We are now engaged in planting large contract branch commercial orchards; many of them containing thousands of trees. They extend in thirteen divisions from the Missouri river to the Wyoming line, and from one mile of the corner of Cherry county down into southern Nebraska. Our success with these orchards has been wonderful. We secured exceptional stands and the trees came into bearing with a rapidity and fruitfulness that surprised and delighted our patrons. We are growing fruit in commercial quantities in far western Nebraska where it was formerly deemed impossible. We are succeeding abundantly where others have repeatedly failed.

Why?

HARDY VARIETIES AND CAREFUL CULTURE

Because our long experience enables us to recommend the proper varieties adapted to each locality, and the peculiar methods of culture that insure success. 


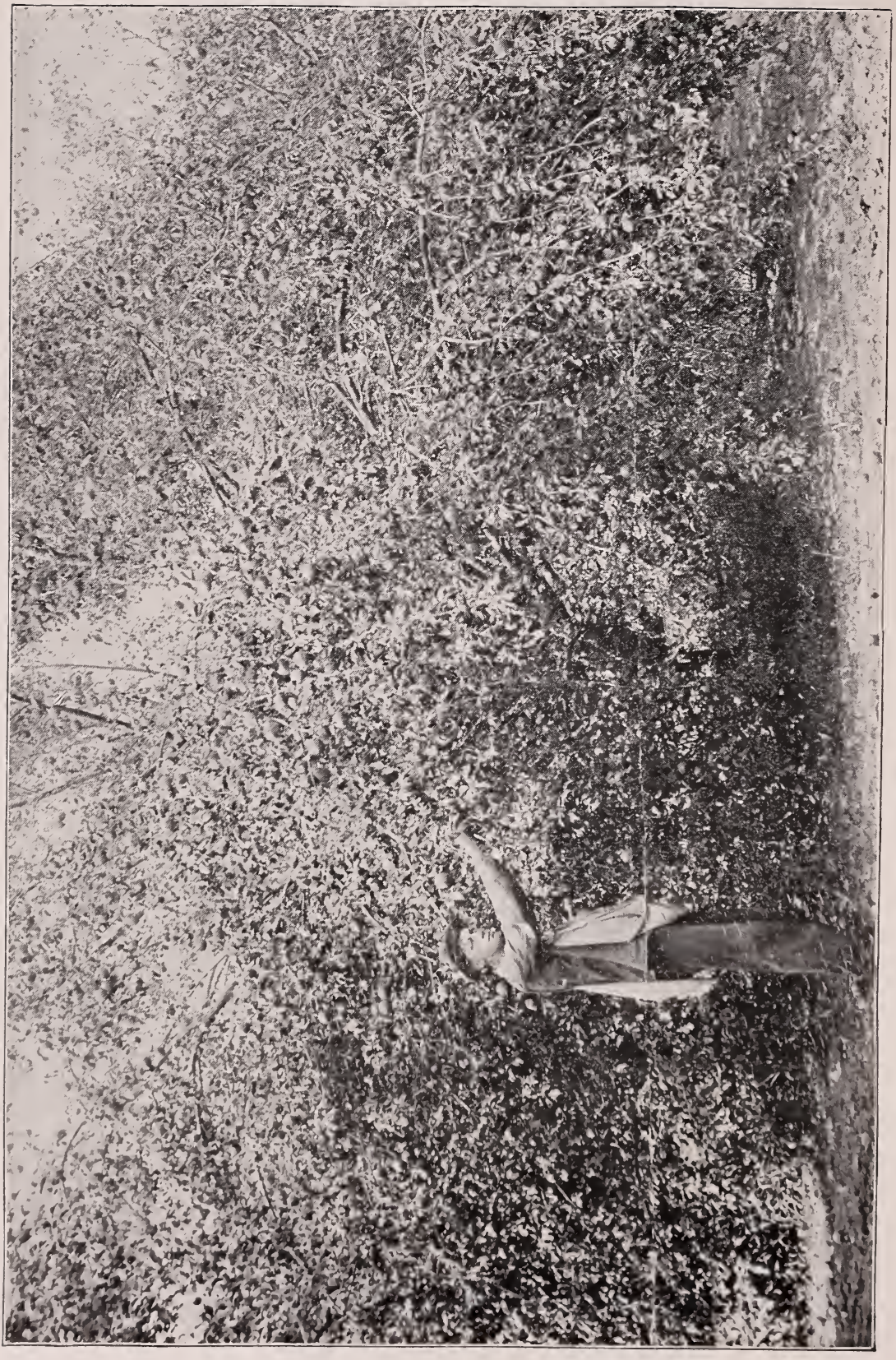

要 


\section{OUR COUPONS SAVE TEN PER CENT}

I wish we knew how to emphasize this point so it would ring in the ears of every intending planter. Some varieties will succeed in Nebraska. Others will not. And of the two lists, the latter is by far the longer.

\section{NEBRASKA IS PECULIAR}

Varieties that succeed along the Missouri river fail in the western part of the state. Some kinds that do well in southern counties are not adapted to the northern. And a long list of the old favorites in the East and South are out of the question here.

\section{VALUABLE EXPERIENCE FREE}

Probably 90 per cent of our customers ask us to select their varieties for them, feeling that we have had invaluable experience while growing up with Nebraska; in serving five consecutive terms as president of the Nebraska State Horticultural Society; and in planting extensively in different localities under varying conditions.

Let us work together for success.

\section{Extra Select Stock of Greatest Importance}

\section{Necessary to Read this to Understand Our Catalogue}

In a long nursery experience nothing has surprised us more than the idea some people have that cheap inferior nursery stock will do to plant. The desire we all have to buy as reasonably as possible is legitimate, but to buy cheaply at the expense of quality is folly.

\section{THE TEN DOILAR HORSE}

Many a man who would be ashamed to drive a ten dollar horse, buys poor nursery stock advertised at a cheap price, either from a false sense of econoiny, or more likely, because he does not understand that there as as many grades in nursery stock as there are in horses.

Of late years the country has been flooded with cheap catalogues containing the same descriptions as our catalogue of Extra Select Stock, offering trees at prices that seem marvelously low. Customers patronizing these firms have found to their disappointment that no nursery will supply a number one tree at a number three price, no mat ter how they may advertise.

"I am another one who has learned his lesson. I bought a lot of cheap trees of one of those cheap nurseries, and they were certainly cheap stuff. They were so little and slender I could scarcely tell where they were after I got them planted. I am tired of buying switches. Now I want you to send me some TREES.'

Custer County.

U. C. STREET.

An inferior tree is a poor investment at any price.

\section{THE HUNDRED DOLLAR HORSE}

If you wish to achieve results and be satisfied with your tree planting experience, let us urge you to plant the best trees you can get.

You plant a tree today, not to use tomorrow, but in years to come. You expect to cultivate, prune, and care for it. What false economy it is in trying to save a few pennies in the cost price to handicap yourself from the outset with an inferior tree.

The hundred dollar horse requires no more feed and little more care than the ten dollar horse. It gives immeasurably better service.

THE BEST IS THE CHEAPEST.

"My orchard induces others to plant trees. I recommend you to everyone. I know you won't sell a man trees not adapted to his locality, and that is the main thing."

Keith County.

G. J. HOLCOMBE. 


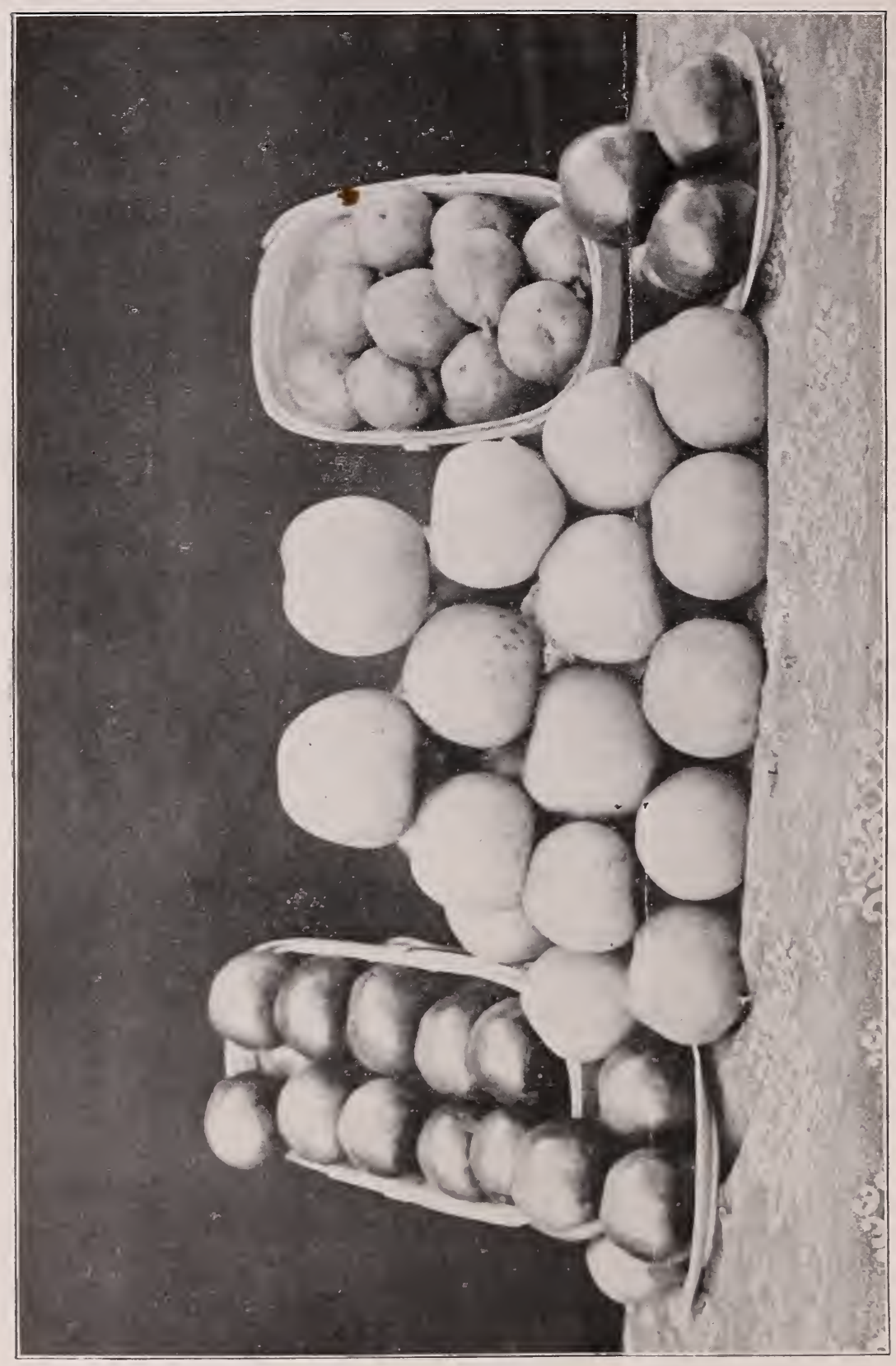

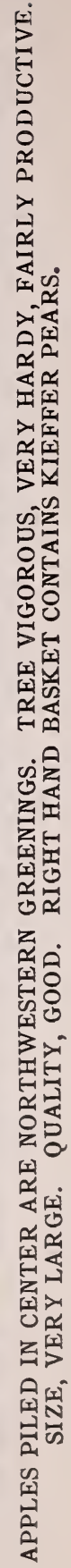


"I am over 81 years old and have set out four orchards. I must say that the trees received from the Crete Nurseries are the finest I ever saw. They are all doing well."

\section{Tree Breeding}

The cheapest way to propagate apple trees for example, is to secure cions from blocks of young nursery stock where they can be cut rapidly. These young trees, however, are like young children-their future quality and productive capacity are unknown.

We are cutting cions from the most fruitful trees in our well known productive orchards.

Why?

\section{THE NEWEST HORTICULTURE}

Because trees can not only transmit hereditary traits like human beings; but by careful selection we can eradicate objectionable characteristics and build up better types.

From one tree we picked twenty-four bushels of fine fruit. This tree was a triumph of horticultural skill, as Nebraska's famous steer Challenger was a triumph of scientific stock breeding.

The wisdom of propagating from trees of such wonderful capacity is at once apparent. Their tendency to extreme fruitfulness is transmitted to all their posterity. The same principle that makes it essential for farmers to perpetuate their best strains of stock, renders it imperative for nurserymen to propagate from their most productive trees.

"My trees bought of Crete Nurseries are already twice as large as those bought from another firm, although the others have been planted a year longer. The Crete trees have a peculiar vitality and hardihood that makes them outstrip all others. No one can sell me trees but the Crete Nurseries."

Custer County.

C. WALL.

There is one infallible test by which you may know if nurserymen are supplying tices of the best possible breeding. Do they have orchards of their own? Are their orchards successful? Do they cut cions fron selected trees in bearing orchards?

\section{A WIDE LIST}

We have one hundred and twenty varieties of apples bearing in our orchards. We also market the product of many varieties of plums, peaclies, cherries, and small fruits.

We are selecting to obtain strains of each variety combining three essential and desirable characteristics-HARDINESS, VITALITY and FRUITFULNESS. So we move forward, ever progressing toward the ideal type.

\section{This Catalogue Describes Desirable Varieties Only}

Every tree, bush and shrub in this list, is the best we have and worth the money.

"Nursery stock received today. The finest I have reccived in twenty years. They are well worth the price. Success to you." Clay County. S. HUNZIKER.

This list has our reputation behind it. The stock is the product of thirty-six years' experience; is of extra quality, well branched, heavily rooted, and WILL GROW and PRODUCE FRUIT.

\section{WE PRESERVE THE VITALITY}

Most nurseries dig their trees in the fall and pile them up in tree cellars with the roots more or less exposed to the drying effects of the air. We bury them completely in earth; root, body, and branch. It costs us about four times as much to follow this extremely careful method; but thirty-six years' experience has proven that our thoroughly protected trees have TWICE THE VITALITY of trees piled up in root cellars.

We go to this added expense for your benefit. We appreciate its significance. Do you? 


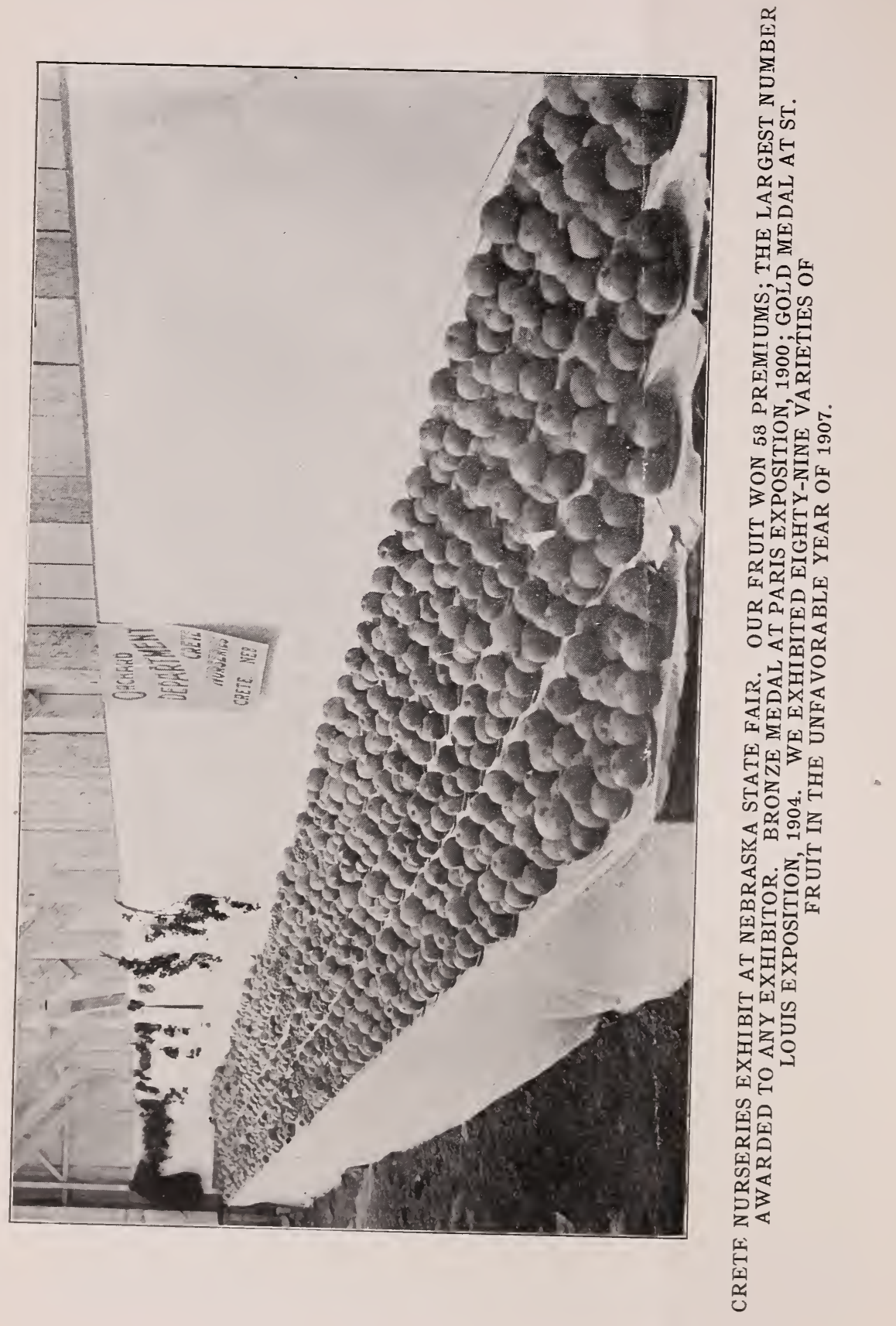




\section{Frequent Shallow Cultivation Retains Moisture}

\section{PREMIUMS AND MEDALS}

The Orchard Department of Crete Nurseries has for years woll numerous premiums at the Nebraska State Fair. In 1905 we won 58 premiums; the largest number awarded to any exhibitor. In the off year of 1907 we exhibited 89 varieties and won fifty premiums.

We were awarded a BRONZE MEDAI, for fruit by the PARIS EXPOSITION in 1900; and a GOLD MEDAL by the ST. LOUIS EXPOSITION in 1904. You are proud of the fact that Nebraska fruit ranks among the best in the world; and we are proud of the fact that Crete Nurseries can produce it.

\section{Apple Trees-Extra Select Stock \\ "Odors of apples! Trees bursting with bloom! \\ Is there so pungent, so rare a perfume? \\ Essence of sunshine, of dew and of rain, \\ Fragrance of flowers and spice of the plain. \\ Here's to the apple, our tastes vindicate! \\ Fort Collins. \\ The queen of the orchard, the pride of our state."}

That the apple is king of fruits is evidenced not only by its general popularity, but by its marvelous productiveness. One of our trees yielded twenty-one bushels of handpicked apples in one crop. Another gave twenty-four bushels. Still another variety yielded 280 bushels of hand-picked apples on one-fourth of an acre, selling for $\$ 210.00$.

Another variety gave an average yield for three years in succession at the rate of 1,500 bushels per acre; this on ground receiving special care. Entire orchards have yielded for us more than 400 bushels per acre.

In the David Hunter branch orchard, supplied by us, 318 miles west of Omaha, apple trees yielded one bushel and three pecks the fifth season after planting. John Blackburn in west central Nebraska picked and sold 60.4 bushels of apples for $\$ 489$; grown on 95 trees. At Mitchell, within twenty miles of the Wyoming line, Ed Scriven sold $\$ 9.00$ worth of Wealthy apples from a single tree in 1903 in spite of the sleet storm of April 29th. that covered his trees with ice.

\section{A GOOD RATE OF INTEREST}

In good seasons the orchard returns take care of themselves. We have therefore selected the worst possible year for our example, as noted below:

Six and one-half acres of our orchard gave 2,500 bushels in a single season, and that during the drought year of 1894 when it was suprising that trees should produce any fruit. The 2,500 bushels sold for $\$ 1,400$, an average of $\$ 216$ per acre. Corn would require from fifteen to twenty years to produce as much money from one acre of ground. This crop, $\$ 216$ per acre, is more than 10 per cent interest on a valuation of $\$ 200$ per acre for ten years.

\section{HARDY VARIETIES}

\section{Ironclad Varieties for Northern and Far Western Planting.}

Yellow Transparent.-Russian. Medium size, pale yellow, juicy, sub-acid. August. Duchess of Oldenburg.-Large; yellow with red streaks; very productive, perfectly hardy; best for cooking. August.

Wealthy.-Minnesota origin; very hardy and free grower; fine quality; very productive. October.

Patten's Greening.-Origin Iowa. Exceptionally hardy and productive. November.

"The order was filled with accuracy and in good shape. Thank you for selection of stock."

Clay County.

LULU A. BEALL. 


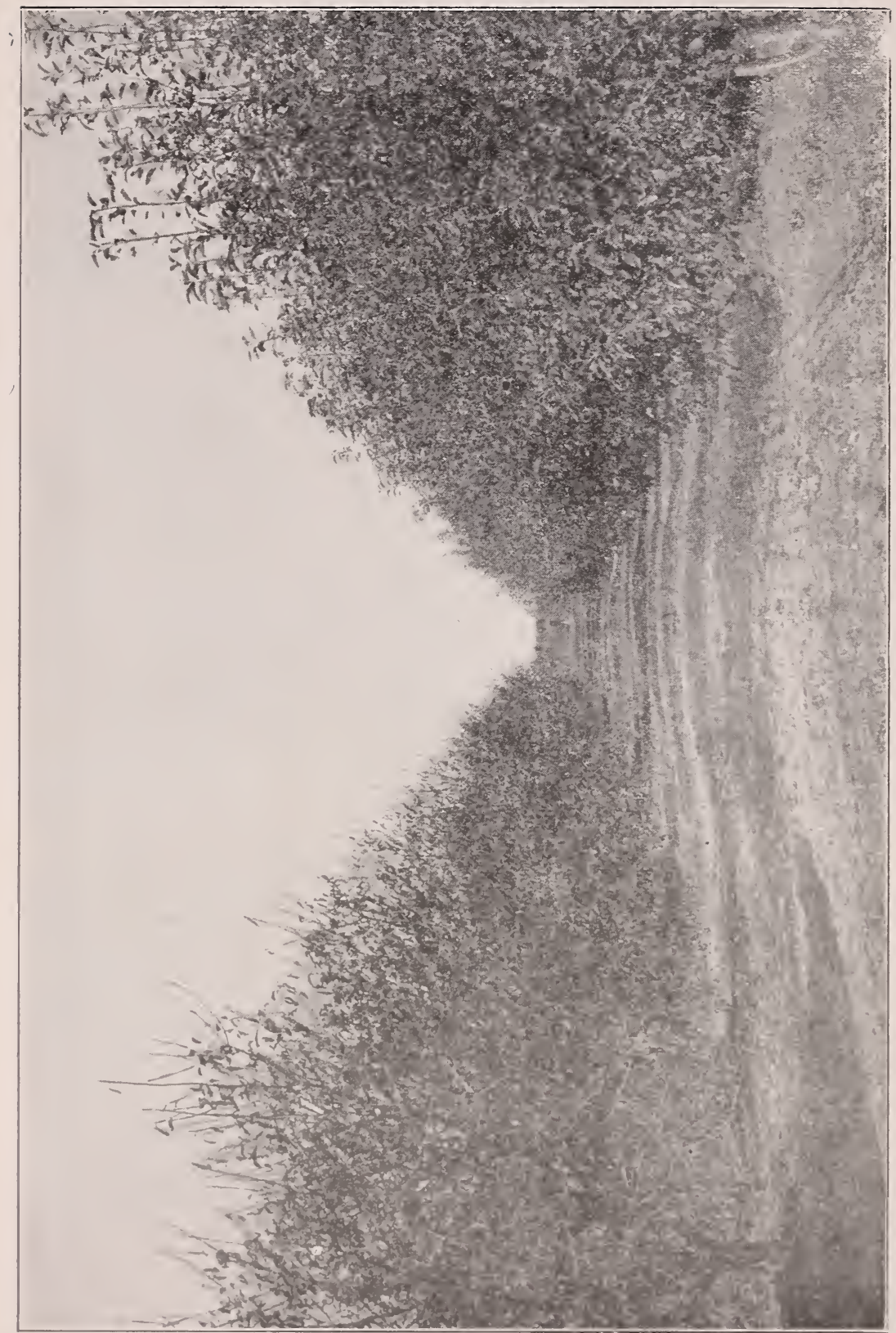

$\vdots$
$=$
$\vdots$
$\vdots$
$\vdots$
$\vdots$
$\vdots$

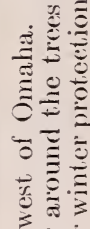

क

을

를

잃

$\therefore 50$

ص을

足三马

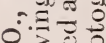

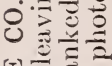

积

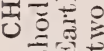

舟

되

闩。

되를

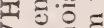

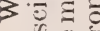

ن 0.

$0=$

4 농

Or.

0 -

伲引方

$<\bigcirc$

던

$x=$

0 잉

位

所 き

는

画

㯊

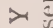

덜

5z

任

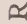

동

궁 


\section{The Greatest Care to Pack True to Label}

\section{APPLE TREES - Continued.}

Longfield.-Russian. Bears young and freely. Medium size and fine quality. October. Iowa Blush. - Tree extremely vigorous. Fine flavor, medium size. January.

Northwestern Greening.-Wisconsin origin. Tree vigorous, healthy; continuous bearer. Fruit large to very large, yellowish green. Late keeper. December.

\section{FOR EASTERN AND SOUTHERN NEBRASKA}

Red June.-Reasonably hardy. Deep red with fine flavor. Size small. August.

Sweet June.-Best summer sweet apple. Strong grower. August.

Maiden Blush. - I Large, flat, yellow with blush. Vigorous and free bearer. Good market sort. September.

Grimes Golden.-Fair size, golden yellow. Juicy, tender, crisp. Fine variety. October to December.

Jonathan.--Fair size. Finest quality. Only moderately productive. Somewhat inclined to twig blight and dropping of fruit. November.

Ben Davis. - Large, handsome; fair quality. Usually healthy. Productive.

Winesap.-Medium size, deep red, good keeper. Moderate grower. Suffers from scab unless sprayed with Bordeaux.

Missouri Pippin.-Medium size. Bears young and profusely. Red striped; fair quality. December to January.

Janet.-(Rawles Genet; Jeniten; Never fail.) Medium size, juicy, crisp, rich flavor. Prolific bearer. Blooms ten days later than most kinds and escapes late frosts. Plant freely of these. February to April. Single trees 34 years planted yielded 30 bushels in 1907.

\section{TREES THAT ARE TREES}

Do not confuse our stock with less carefully propagated trees such as are often sold at a seemingly low price. Every tree is of such constitution, health and quality as will speak for itself on arrival, and bear fruit in years to come.

"First, I appreciate your promptness in sending the trees. Second, I appreciate the moderateness of your charge. Third, I appreciate most of all the very strong and choice trees you sent me. They are fine indeed." Hamilton County. I. R. BRANSON.

\section{IRONCLAD VARIETIES}

Extra select grade, 5 to 6 feet. Each and every one a fine tree that will not fail to please. 25 cents each. $\$ 3.00$ per dozen.

\section{EASTERN AND SOUTHERN LIST}

Extra select grade, 5 to 7 feet. Fine trees with our reputation behind them. 25 cents each. $\$ 2.50$ per dozen. $\$ 18.00$ per 100 .

For lighter sizes see Special Cheap List.

\section{Crab Apples}

\section{EXTRA SELECT STOCK}

No trees are hardier, more durable, or more productive than crab apples. They serve a wide variety of uses in the making of preserves and jellies, and for canning purposes.

At Mitchell, within twenty miles of the Wyoming line, Ed Scriven marketed \$8.00 


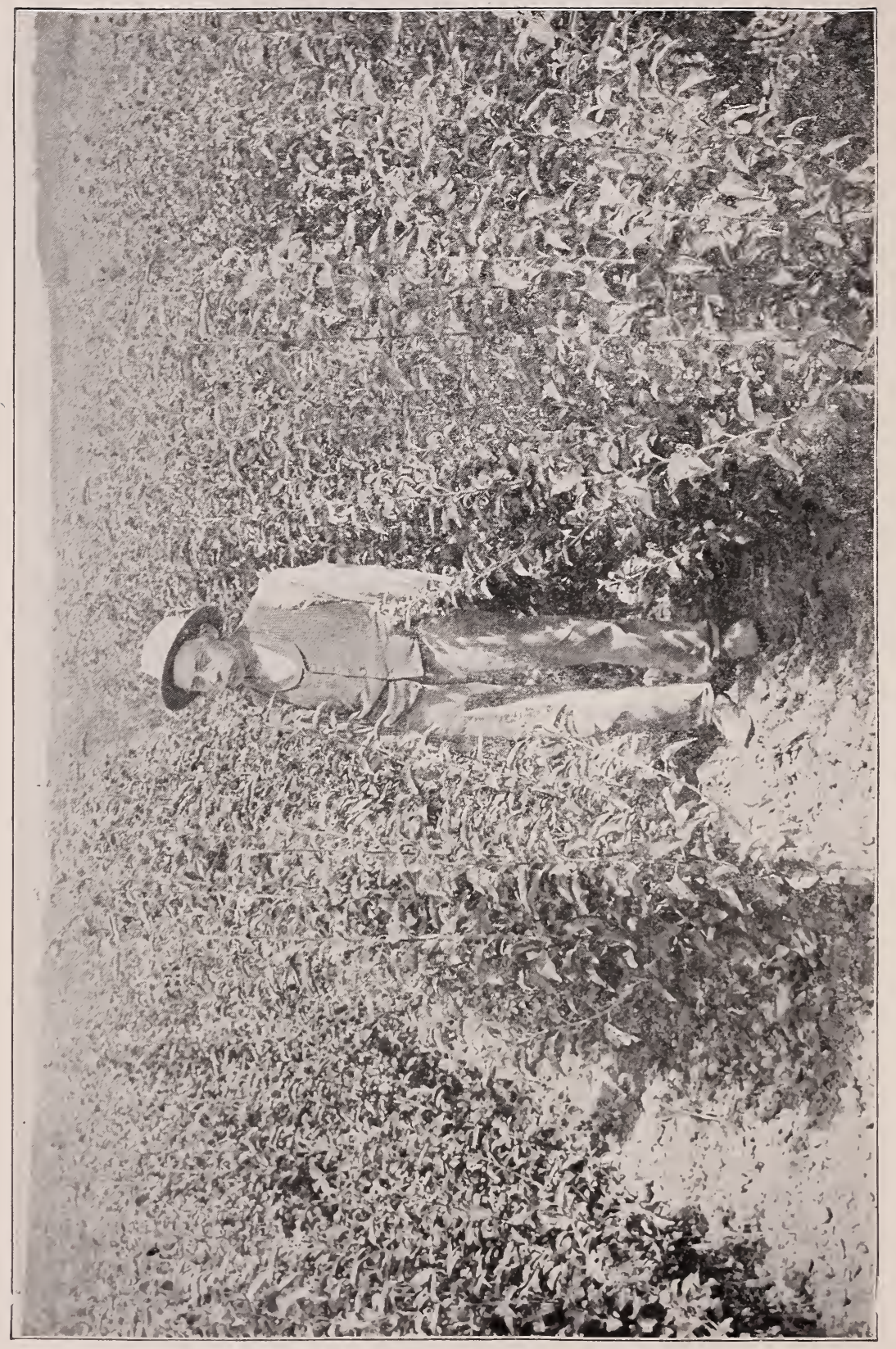

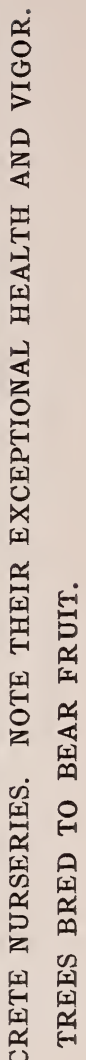




\section{Stock Guaranteed to Reach You in Perfect Condition}

worth of Whitney No. 20 crabs from a single tree in spite of the ice storm of April 29th of that year.

Whitney No. 20. - Large, more like a medium sized fine flarored apple. Good to eat as well as for canning and preserving. Yellowish green, red striped. A great bearer and very hardy. August.

Florence.-Hardy, productive, beautiful color. We can supply other varieties also. Extra select grade, 5 to 6 feet. Our best. 25 cents each. $\$ 3.00$ per dozen.

\section{Cherries}

\section{EXTRA SELECT STOCK}

Cherries are especially adapted to Nebraska. They come into bearing quickly, yield abundantly, succeed universally, and are so easily grown that no one need be without this, the most popular of fruits.

\section{HARDY ROOTS}

Our trees are all budded on Mahaleb stock which makes an exceptionally desirable ruot and does not sprout.

\section{QUICK RETURNS}

Our Extra Select trees commence bearing in two years.

"Am much pleased with the trees received two years ago. All are growing. The cherries bore excellent fruit last season. I will be glad to help advertise your nursery stock at any time." Lancaster County.

MRS. J. B. DAY.

One of our orchards yielded $\$ 4.00$ from single trees the sisth season after planting. At the age of eleven years single trees gave us three and one-half bushels, and at eighteen years 100 quarts. We have raised single crops of 400,500 and 700 bushels each.

In 1904 we raised one hundred and ten quarts of cherries on an eight-year-old tree.

Early Richmond. - The well known early red cherry. Ripens first. Very productive. Montmorency.-Ripens next. Not so productive as Early Richmond but larger size and finer quality.

English Morello. - Late, black, last to ripen. Rich for canning. Subject to shot hole fungus east of North Platte.

Stick to these well tried thoroughly proven varieties. Let others experiment. Sweet varieties and Dukes will not succeed in Nebraska.

Extra Heary Grade. (Special.) We offer a few handsome six-foot trees, an inch or more in diameter, shapely and ornamental enough for lawn planting. These are splendid trees, commence bearing in one year, never fail to please. 60 cents each.

Extra Select Grade. Eighty per cent of our customers order this grade. 5 to 6 feet. 50 cents each. $\$ 6.00$ per dozen.

Smooth two year, 4 to 5 feet. 45 cents each. $\$ 5.00$ per dozen.

A lighter grade, two year, 3 to 4 feet. 30 cents each. $\$ 3.00$ per dozen.

"Out of about 100 fruit trees set out last spring, only two failed to grow; the rest were hearty and strong."

Cheyenne County.

C. J. OSBORN. 
"Trees arrived in excellent shape. I think they are by far the best trees that have come into this town this spring." Kearney County.

B. J. HALBERG.

\section{Plums \\ EXTRA SELECT STOCK}

The cultivation of plums is rapidly increasing. A family supply of this juicy fruit can be grown on a small space since they succeed best in a group or cluster where they can pollenize one another.

We have found it advantageous to mix sereral varieties so as to secure a continual supply of pollen during the blooming season.

\section{TRIMMING}

The plum tree in Nebraska is vigorous in growth and requires cutting back each spring to prevent an overweight of fruit at the ends of long branches. Trimming back produces a stockier tree and prevents splitting.

\section{FOR NORTHERN AND WESTERN PLANTING}

Sandoz.-Northern Nebraska origin. Ripens earily, hardy and productve. Particularly desirable for northern and western planting. Color, red.

De Soto.-Medium size, red, bears young and profusely. Hardy and very desirable.

Hawkeye. - Very large, dark red, hardy and productive.

Wolf.-Large, dark red, fine for cooking and canning because free stone. Vigorous grower. Very hardy.

Wyant. - Purplish red. Large. Iowa origin. Excellent quality, hardy and very productive.

Lombard.-Violet red. Flesh yellow and juicy. A great bearer. Tree vigorous.

German Prune.-Purple. Medium size. Juicy and rich. Vigorous and productive.

First class trees, 5 to 6 feet, 50 cents each. $\$ 5.00$ per dozen.

Choice trees, 4 to 5 feet, 40 cents each. $\$ 4.00$ per dozen.

See Special Cheap List For Lighter Grades.

\section{Peaches}

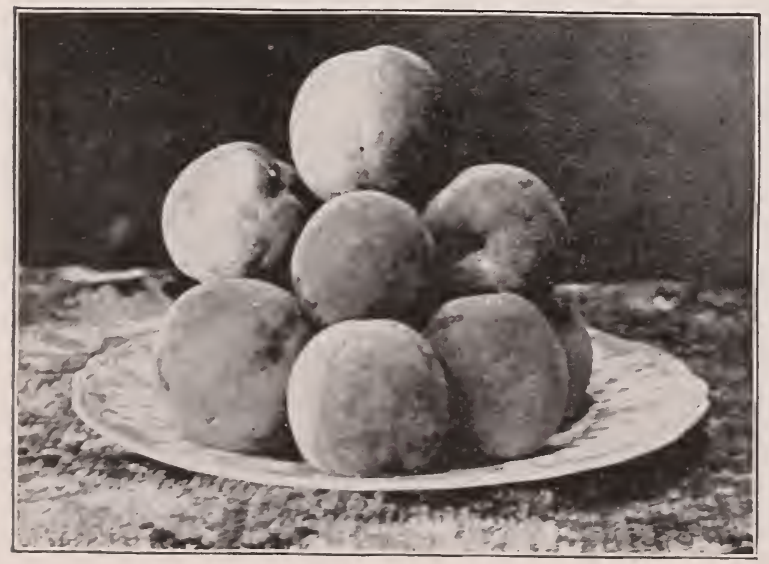

THE WRIGHT PEACH
During the past twelve years no peach has come to the front like the Wright. Of all the peaches we have tested it stands unrivaled for hardihood. The fruit buds have endured 25 degrees below zero while the trees themselves have withstood 40 degrees below zero. This wonderful record makes it the King of Hardy Varieties for universal plantng.

In the trying season of 1903 when nearly all ot her fruit had been destroyed by the sleet storm it fruited abundantly 317 miles west of Omaha. In seven year old orchards in Lincoln County the Wright has fruited four times. 
"Plum trees received yesterday in good shape. You are more than generous and I thank you very much." Douglas County.

JOS. WILKINSON.

"Received the trees yesterday in good condition and just the kind I have ordered."

Colfax County.

MR. JOHN MACA.

\section{PEACHES-Continued.}

In Phelps county this remarkable variety has yielded two bushels to the tree three seasons in succession, the fruit selling for $\$ 2.00$ per bushel. The quality of this luscious peach is such that commercial orchardists who have all the varieties to choose from use the Wright for their own supply of canned peaches. Color white with pink blush. Free stone. September.

This variety is hardiest, when propagated in the form in which we supply it, on its own root, without budding.

"Last spring I bought 100 Wright peaches of you. I was so well pleased that I will send you another order." Adams County.

J. W. PLUMMER.

In order to encourage the planting of this wonderfully hardy, fine flarored peach, we have put the price so low that no one can afford to be without them.

5 to 6 feet, 30 cents each, $\$ 3.00$ per dozen, 50 for $\$ 8.00,100$ for $\$ 14.00$.

4 to 5 feet, 20 cents each, $\$ 2.00$ per dozen, 50 for $\$ 6.00,100$ for $\$ 10.00$.

3 to 4 feet, 15 cents each, $\$ 1.50$ per dozen, 50 for $\$ 5.00,100$ for $\$ 8.00$.

Russell. - Large, dark red, very productive. Next to Wright in hardihood. Particularly fine quality. Late August. Free stone. A famous Nebraska favorite, originated by and named after Nebraska's greatest peach grower.

In one size only. Splendid trees of bearing size, 5 to 6 feet, shapely and ornamental enough for lawn and garden planting, 35 cents each. $\$ 4.00$ per dozen.

Champion.-Large, creamy white, with red cheek. Sweet, rich, juicy. Free stone. Early September.

Crosby.-Medium size; yellow, good quality; hardy. Free stone. September.

Greensboro.-Yellowish crimson; flesh white, juicy; of excellent quality. Free stone. August.

Triumph. - Large: yellow, nearly covere w with red. Early August. Cling. Hardy.

Early Rivers. - Nedium size; creamy white with delicate pink cheek; flesh melting and juicy with rich flavor. Free stone. July. One of the best early sorts.

Alexander.-Tree vigorous and productive. Cling. July. One of the best.

Extra select Grade, 5 to 6 feet, 30 "cents each. $\$ 3.00$ per dozen.

Select Grade, 4 to 5 feet, 25 cents each. $\$ 2.50$ per dozen.

\section{Pears}

Pears, like peaches, have a tendency to put on too much wood, and should be planted in the poorest soil and most exposed situations. Do not apply manure or other fertilizers, but use an abundance of coal ashes. A wagon load to each four trees is not too much.

"My peach trees ordered two years ago are ten feet high and the Wrights bore splendidly last year. You will hear from me with orders yearly hereafter."

Seward County.

F. B. TIPTON.

"Trees were delivered at our door one week ago. They did not stop growing. We are pleased with all the stock received and many thanks for the coupon stock."

Cass County.

MRS. J. A. PHEBUS. 


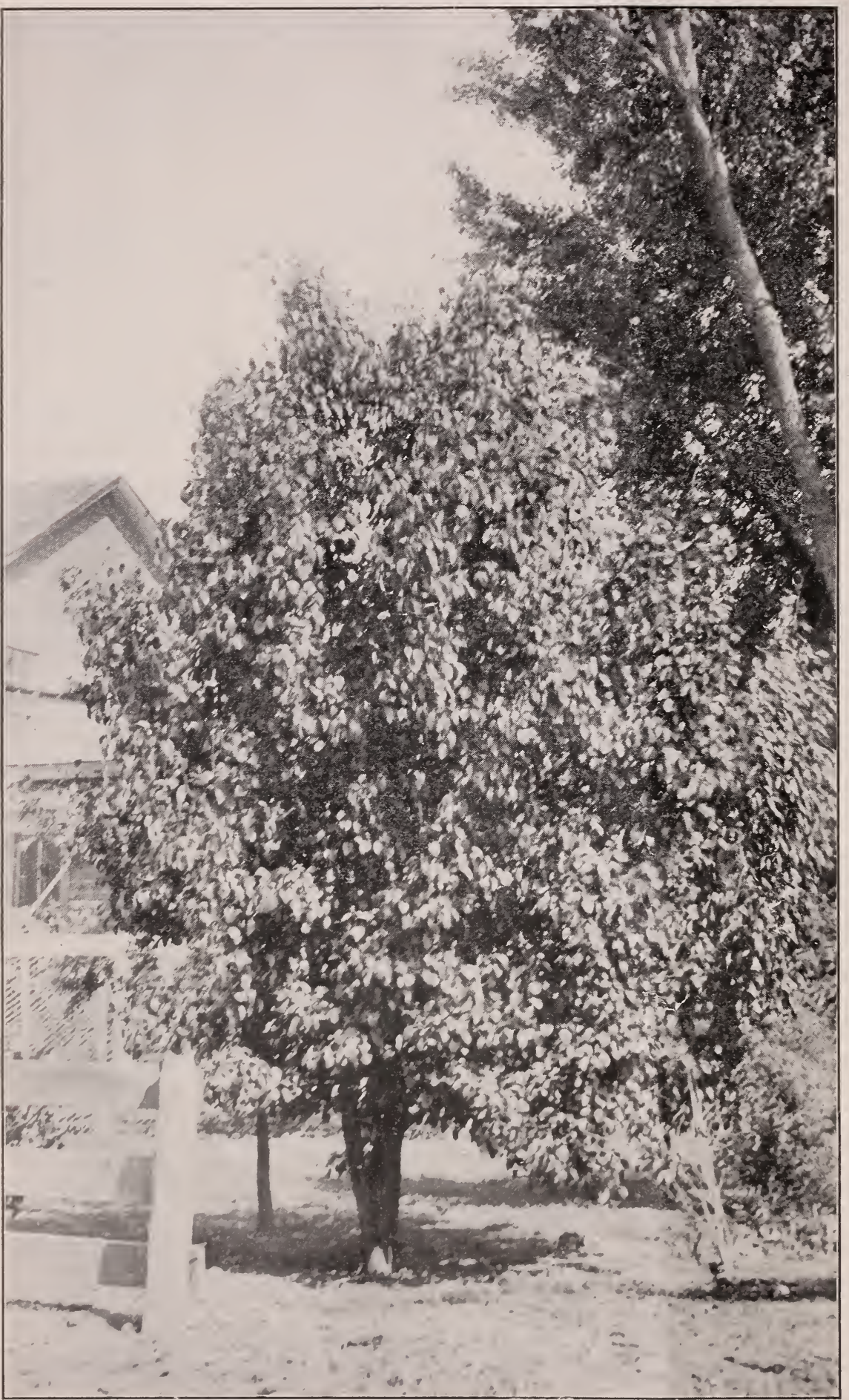

THE WARNER PEAR

Hardy, Productive, Free from Blight, Excellent for Family Use. 


\section{PLEASE NOTICE OUR CASH COUPONS}

\section{PEARS-Continued.}

\section{THE WARNER LEADS}

Of the many varieties we have tested in thirty-six years, the Warner is by far the best. It has a remarkable history. Originally from Germany it fruited for seventy-five years in Pennsylvania before being brought to Ohio. There the tree from which me propagated our first stock fruited for seventy-five years in the door yard of the Warner family. Eighteen years ago we brought the variety to Nebraska.

One hundred and sixty-seven years of history. Years before the Declaration of Independence this fine pear was yielding its abundant harvests of juicy fruit.

\section{ITS PECULIAR GROWTH}

The wonderful hardihood of the Warner is largely due to the fact that it grows slowly, ripening its wood early. It is ready for winter when winter comes. Another strong feature is its remarkable freedom from blight.

Our parent IVarner tree has given us eleven consecutive crops of fruit. It has never missed a crop since it began bearing. If you are fond of pears the Warner will grow them for you.

Our first trees were sold at $\$ 1.00$ each. In order to encourage the planting of this, the best of all pears for Nebraska, we make the following offer:

Strong one year, 4 to 5 feet, 60 cents each. $\$ 6.00$ per dozen.

3 to 4 feet, 50 cents each. $\$ 5.00$ per dozen. 2 to 3 feet, 25 cents each.

Pear growing is not commercially profitable in Nebraska. For experiment the following varieties promise best:

Flemish Beauty.-Large, juicy, rich. September.

Seckle.-Yellowish brown. Fine grained. Fruit small, but fine quality. September. Anjou. - Large, rich flavor. October to January.

Kieffer.-Vigorous grower. Should be pollenized by other varieties. I arge; best for cooking. October.

Duchess de Angouleme. - Very large. Excellent quality.

Plant the Duchess in dwarf form only. The other varieties succeed best when grown as standards.

First class trees, 5 to 6 feet, 50 cents each. $\$ 5.00$ per dozen.

\section{Grapes}

"Of grapes grown on Nebraska's sward I've had my fill complete;

For which I'm pleased to thank the Lord

And nurseries at Crete."-Bixby in State Journal.

\section{EXTRA SELECT VINES}

The grape is one of the quickest and surest of small fruits. It can be planted anywhere, and hillsides, unsuited to other crops, make good vineyards. Enriching the soil with manure or any other fertilizer produces the finest fruit.

"Two years ago I purchased 100 grapevines of you. You sent me 108; 107 grew. Some vines had five bunches of grapes the same season of planting. I wish to purchase more trees and vines from you the coming spring."

Harlan County.

JOHN B. YARNELI. 


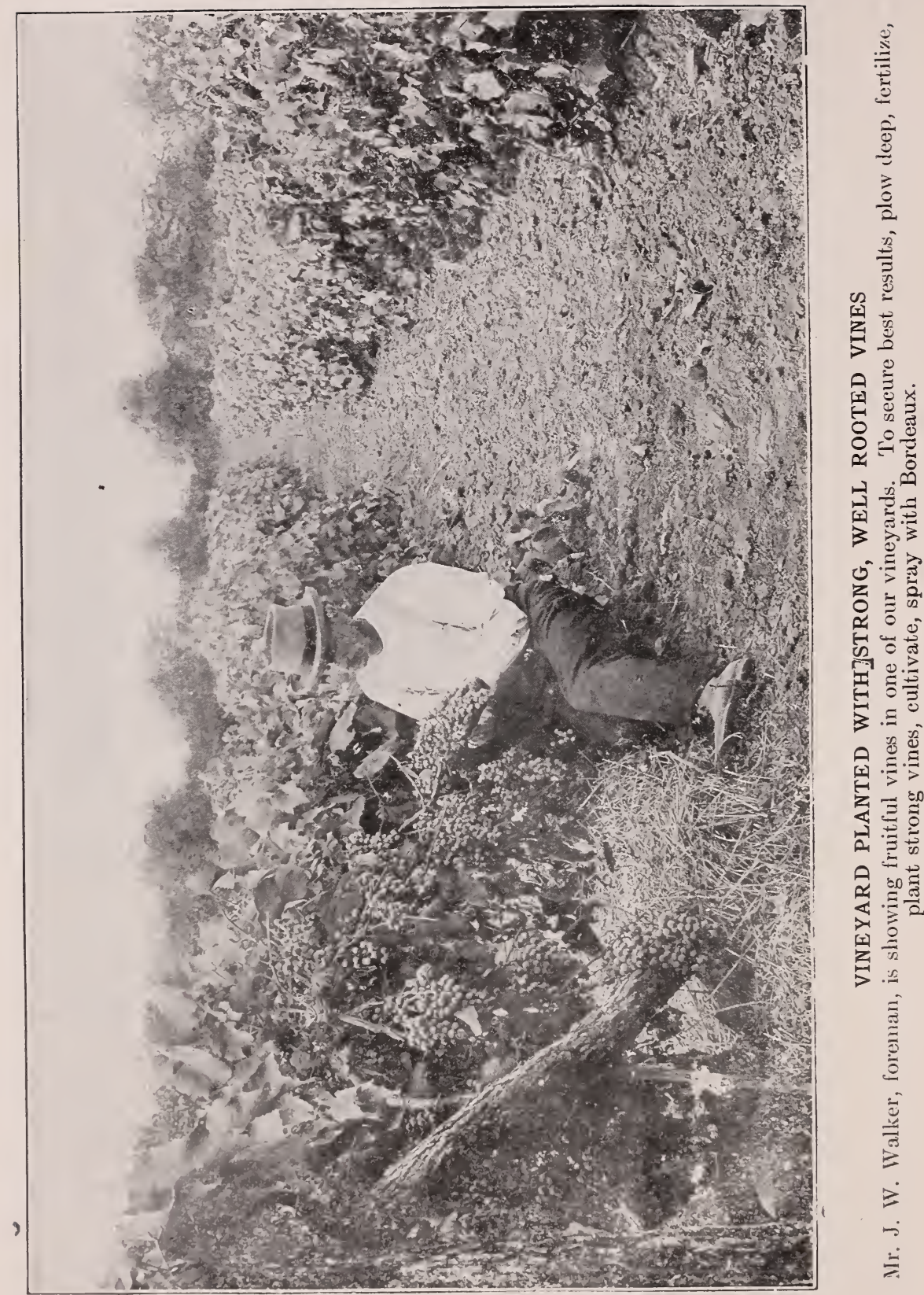




\section{PRUNING AND COVERING}

No other fruit requires so severe pruning as the grape. Cut off three-quarters of the new wood each fall, leaving but five or six buds on each new lateral. During November cover the vines with earth, or straw and earth, as a winter protection.

\section{AN ABUNDANCE OF ROOTS}

The vines we offer are not light stock such as could be sent by mail. The tops are well developed, with strong, healthy buds. The roots are long and heavy. Vines so equipped sometimes fruit the first season.

\section{"THE PROOF OF THE PUDDING"}

In the dry season of 1904 we marketed from our successful and productive vineyards forty-five hundred and fifty baskets; a yield which amounted to about $\$ 136$ per acre. Have never had a complete failure in nineteen years.

Moore's Early. - The earliest black grape. Large, with delicious flavor.

Worden.-Black, ripens after Moore's Early. A fine flavored seedling of and improvement upon the Concord.

Concord.-Black, ripens after Worden. Most popular, most productive of all.

Empire State, Niagara and Elvira, ripening in the order named, are the hardiest white varieties.

Grapevines are graded into five grades, from Exxtra Select 2 year to 2 d class 1 year Below these grades the culls are sometimes offered at $\$ 2.00$ per 100 . We offer nothing but Extra Select and Select, the highest of the five grades.

Extra Select Grade, 2 year Concord, $\$ 1.25$ per dozen.

Select Gradé, Concord, $\$ 1.00$ per dozen.

All other varieties, Extra Select 2 year Grade, $\$ 1.50$ per dozen.

\section{Strawberries}

\section{EXTRA SELECT STOCK}

A strawberry grower who raised twenty-five millions of plants last year remarked recently: "There is more gold to be found in the strawberry bed than in any other small fruit." Certain it is that nothing gives such quick and satisfactory returns with so little aare as strawberries. 'They are the earliest fruit to ripen, and with a proper selection of varieties one may have a continual supply of this luscious fruit for a month or six weeks.

\section{PLANT THEM IN THE SPRING}

Strawberries should always planted be in the spring. Summer and fall planting is unsafe and unsatisfactory in Nebraska.

\section{OLD OR UNFERTILIZED PLANTS}

Don't get plants from your neighbor's old bed. We urge this upon you, not because we have plants to sell, but for two very important reasons.

1.- Strawberries are of two classes, staminate and pistillate. Pistillate varieties must be fertilized to produce fruit. The pistillate are most productive when rightly pollenized.

In nine cases out of ten your neighbor does not know which of his plants are staminate and which are pistillate. We have often seen plats of fine, healthy plants taken from old beds destitute of fruit because of lack of pollenization

2. - Strawberry plants deteriorate after three years. The older the plants the smaller and more inferior the fruit. Your friend is really doing you no kindness in giving you plants from his old bed. 


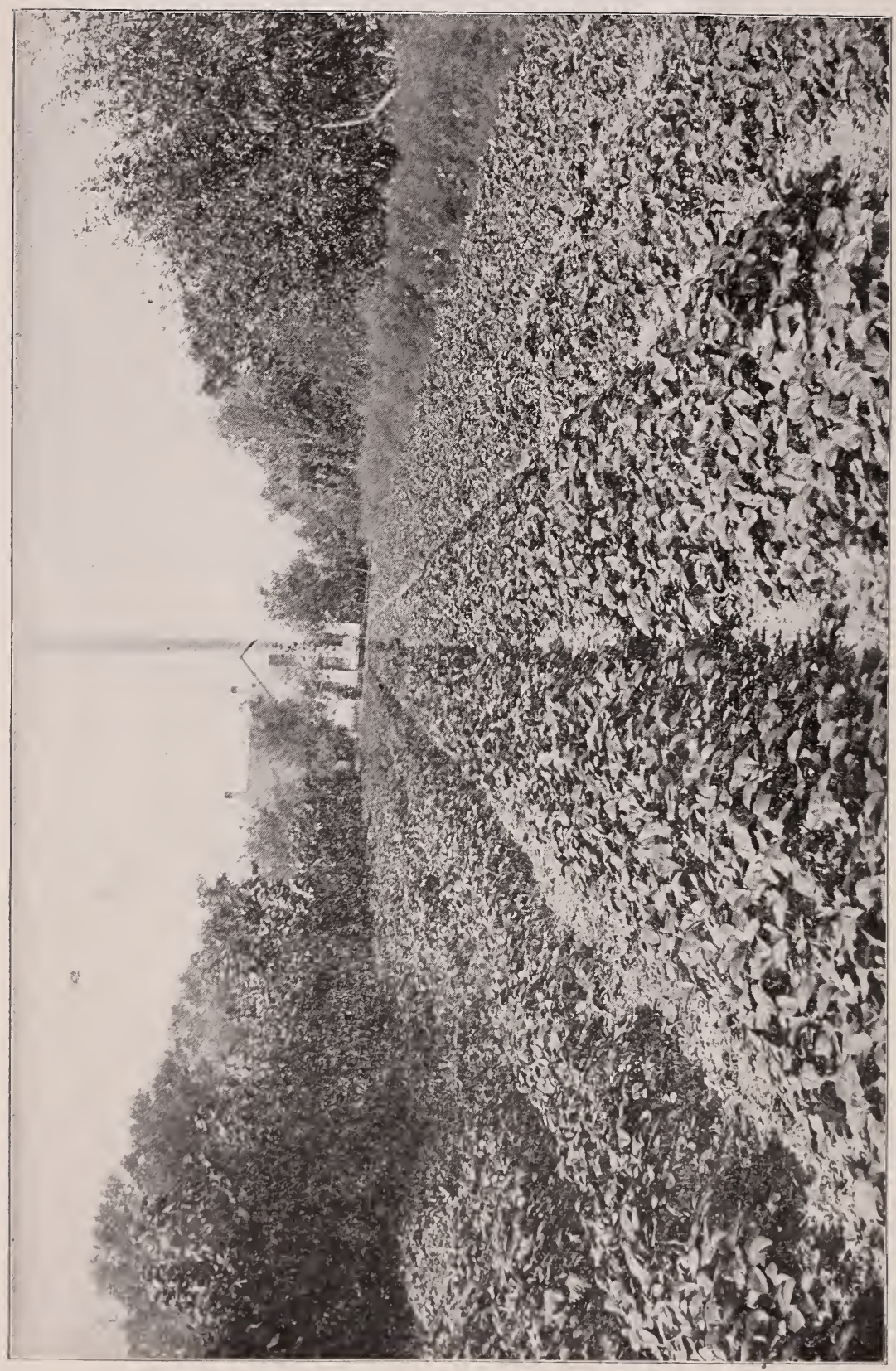

点

P

Ex

$>$

75

듬

包贶

世忌

$\alpha \approx$

Aิ जि

4 또임

되요

I $\alpha$

L 0

때응

동

(x) Z (

'뇽

Aค

乙되스

(4)

뙤응

도의

겁금

क्वे

स及

0 is

曲

돈표

욤ำ

0

$\Leftrightarrow>$

सा

约 은

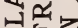

四红

궁

$\alpha \propto ⿻ 上 丨)$

다을

ค

$\beta>0$

$\varangle$

田

约

吕 뛰

$0 \stackrel{2}{\mu}$

$\leftarrow 0$

될도

咨。

更

at

D

砧

묑 


\section{SIZE OF STRAWBERRY BED}

Many persons believe a hundred or two plants sufficient for a family supply, having little idea of how small a plat that number will plant. When one reflects that an acre holds 14,000 plants set one foot apart, three feet between rows; and that five hundred plants only fill one tirenty-eighth part of an acre, it is apparei.t that at least 500 to 1,000 plants should be set to furnish an ample family supply. The cost is very slight. One cent buys two plants.

Pistillate kinds-Warfield, Crescent.

In staminate rarieties Senator Dunlap is hardiest and most productive.

Senator Duniap. - A well tested, wonderfully productive variety. One of the best for universal plarting. Bright red, good size, exvellent quality.

Warfield.-Plant with the Dunlap. Its great beauty, productiveness and vigor make it exceedingly popular. Ripens with the ('rescent and is sucerseding that rariety as a reliable market sort.

We are careful to send out a sufficient number of staminate plants to pollenize the pistillates. Strawberry plants should be shipped by express separate from freight orders.

Fine, thrifty young plants; our rery best, $\$ 1.00$ per $100 ; \$ 4.00$ per $500 ; \$ 7.00$ per 1,000 .

\section{Raspberries}

\section{EXTRA SELECT STOCK}

Our raspberries have fine, healthy tops, with abundant masses of fibrous roots. After testing all other varieties we have narrowed our list down to the following:

Loudon. - The best red midseason berry. Its points of superiority are vigor of growth: large fruit of a rich dark crimson color; marvelous productiveness and hardihood, enduring winter without protection, usually fridits the same season planted Kansas.-Strong vigorous growers. The hest black cap; standing extremes of drought and cold, and bearng immense crops. At Bayard, Nebraska, up near the Wyoming line, James Burns successfully fruited the Kansas for a number of years without winter protection. It bore fruit the year following the severe winter of 1898-9 when the thermometer fell 40 degrees below \%ero.

Cardinal. - Fred Wellhouse, President of Kansas Horticultural Society, says: "The introduction of this raspberry will add greatly to the wealth of the country, because of its inherent great vigor and exceeding productiveness." The wood is hard and almost thornless. The berries are large, dark red, firm, and with a wonderfully agreeable, rich flavor.

Cumberland.-Fruit very large, black, firm. Yields freely. Exceedingly healthy and vigorous. Fine quality and very popular.

Extra Select Grade. Loudon and Kansas, $\$ 1.00$ per dozen; $\$ 5.00$ per 100 . Cardinal and Cumberlard, $\$ 1.00$ per dozen, $\$ 6.00$ per 100 .

\section{Blackberries}

\section{EXTRA SELECT STOCK}

The secret of raising blackberries successfully is the straw mulch. Cultivate the plants the first summer. In the fall surround them with a straw inulch two feet deep. Let this remain on the ground and add to it every winter as it settles.

During the summer this mulch holds the moisture, keeping the ground underneath moist and coul. It also prevents the growth of weeds. In the winter it protects the bushes. 


\section{BLACKBER RIES-Con tinued.}

Many of oxir customers are raising an abundance of blackberries by this method where previously they failed. Our own plantation handled in this manner is yielding at the rate of 100 bushels per acre.

Snyder. - The best known and most universally planted blackberry of all. Exceedingly productive and very hardy. Extra Select Plants, $\$ 1.00$ per dozen; $\$ 4.00$ per 100.

Mersereau. - A fine, new, midseason berry. Very productive, hardy, and of great size. Has withstood twenty degrees below zero without injury. A great acquisition. Do not fail to include some of these delicious berries in your order. Extra Select Plants, $\$ 1.25$ per dozen.

\section{Currants}

\section{EXTRA SELECT BUSHES}

Our currants are not slips or cuttings that could be sent by mail, but are fine, heary bushes, that commerice bearing the second year.

Victoria.-A late, red currant of good quality. Especially esteemed by western growers. Cherry and Fay's Prolific.-Both good varieties. Red.

White Dutch.-Productive and mild flavor.

Wilder.-A fine new currant. Bunches and berries of large size. Bright red color, splendid quality.

Wilder.---Extra Select Grade, $\$ 1.50$ per dozen.

All other varieties, Extra Select Grade, $\$ 1.25$ per dozen. Fine heary bushes.

Select Grade. Lighter plants. \$1.00 per dozen.

\section{Gooseberries}

\section{EXTRA SELECT BUSHES}

As in the case with currants, our gooseberries are heavy, well rooted, two-year-old bushes, that commence bearing the second year.

Houghton.-The well known red gooseberry, productive and of good quality.

Downing. - The best gooseberry of all. Berry very large; twice the size of Houghton and of light green color. A handsome, productive bush. Berries hang thick in close rows beneath.

Extra Select Grade. Fine heary bushes. Houghton, $\$ 2.00$ per dozen. Dorning, $\$ 2.50$ per dozen.

The supply of gooseberry bushes in the United States is very short this season. Hence higher prices.

\section{Asparagus and Rhubarb or Pie Plant}

It requires about 100 asparagus and 25 rhubarb plants for a family slipply. We send the best.

Asparagus, $\$ 2.00$ per 100 . Rhubarb, $\$ 1.00$ per dozen roots.

"Your trees arrived and are above expectation."

Phelps County. 


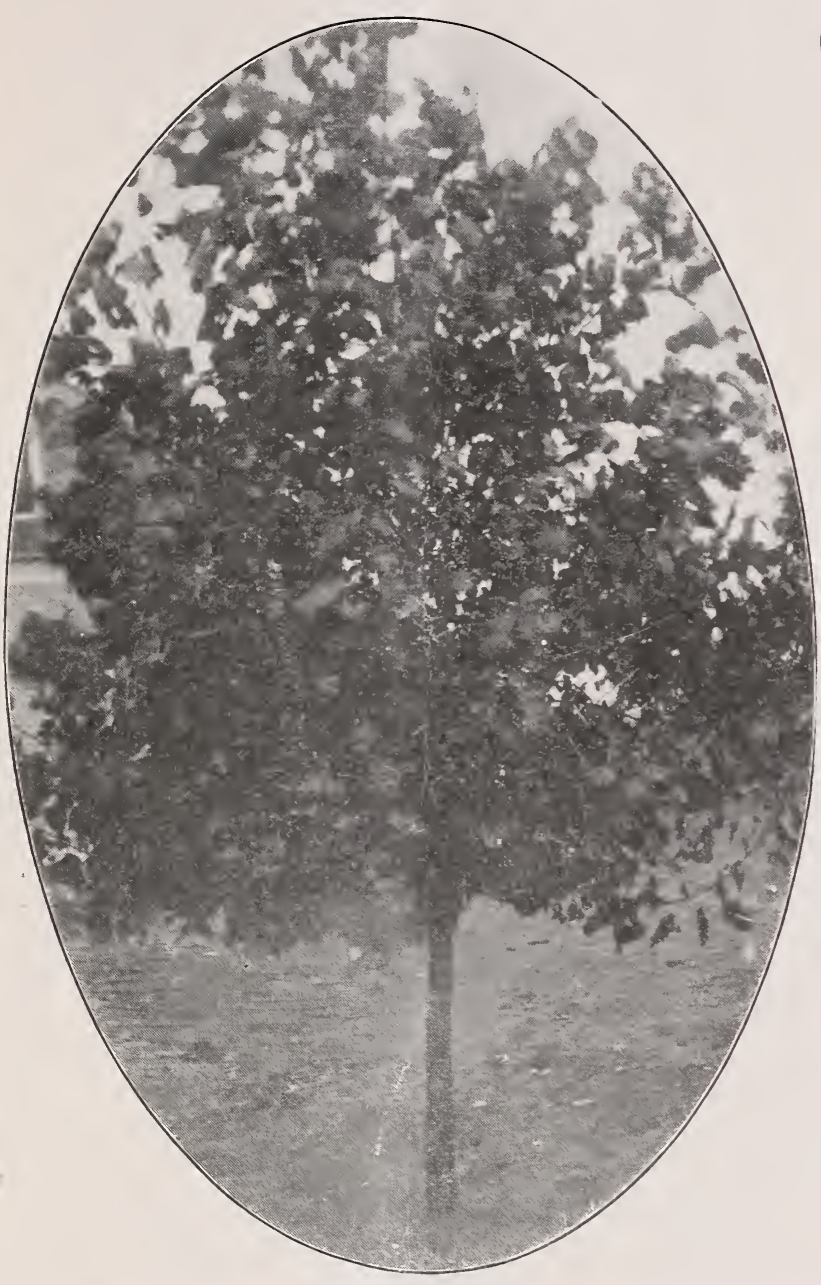

ONE OF OUR EIGHT TO TEN FOOT CAROLINA POP. LARS IN CUSTER COUNTY, FIFTEEN MONTHS AFTER PLANTING.

\section{Ornamental Trees}

\section{EXTRA SELECT STOCK}

Nothirig can take the place of fine shade trees in improving property. Those listed below have been carefully trained in the nursery; are straight, smooth and evenly branched. They are especially adapted to lawn and street planting.

Carolina Poplar. - A hardy shade tree with a beautiful, broad spreading, symmetrical top and large, bright yreen leaves. Unexcelled for quickness of growth and will improve property quicker than any other tree.

It gives a luxuriant effect to places where other trees appear starred, and will grow persistently if given half a chance. Two hundred eight to ten foot trees were planted along a public road in Custer county without the loss of a single tree. Some were planted in the sod. They had no cultivation and not a drop of water aside from the regular rainfall.

The illustration shows one of a large number of these 8 to 10 foot trees planted by R. G. Farritor on his home grounds in Custer county, supplied by us. The photograph, taken only fifteen months after planting does not do justice to the luxuriant beauty of his trees. Mr. Farritor says: "In fifteen months these handsome trees have made my bare grounds look like a thrifty young forest. I would not take $\$ 500$ for the improvement to my property." Mr. Farritor is a farmer. This is a tree that will grow on the farms as well as in the cities, where it has long been exceedingly popular.

This is entirely different from and must not be confounded with the old Lombardy Poplar, which grew tall and narrow, and was worthless in every way.

Every one who plants these trees wants more. The demand for them is unprecedented. Do not fail to include them in your order.

10 to 12 feet, 50 cents each; $\$ 6.00$ per dozen. 9 to 10 feet, 40 cents each; $\$ 4.50$ per dozen. 8 to 9 feet, slender, 30 cents each; $\$ 3.50$ per dozen. $T$ to 8 feet, 25 cents each; $\$ 3.00$ per dozen. 4 to 6 feet, $\$ 10.00$ per 100 . 


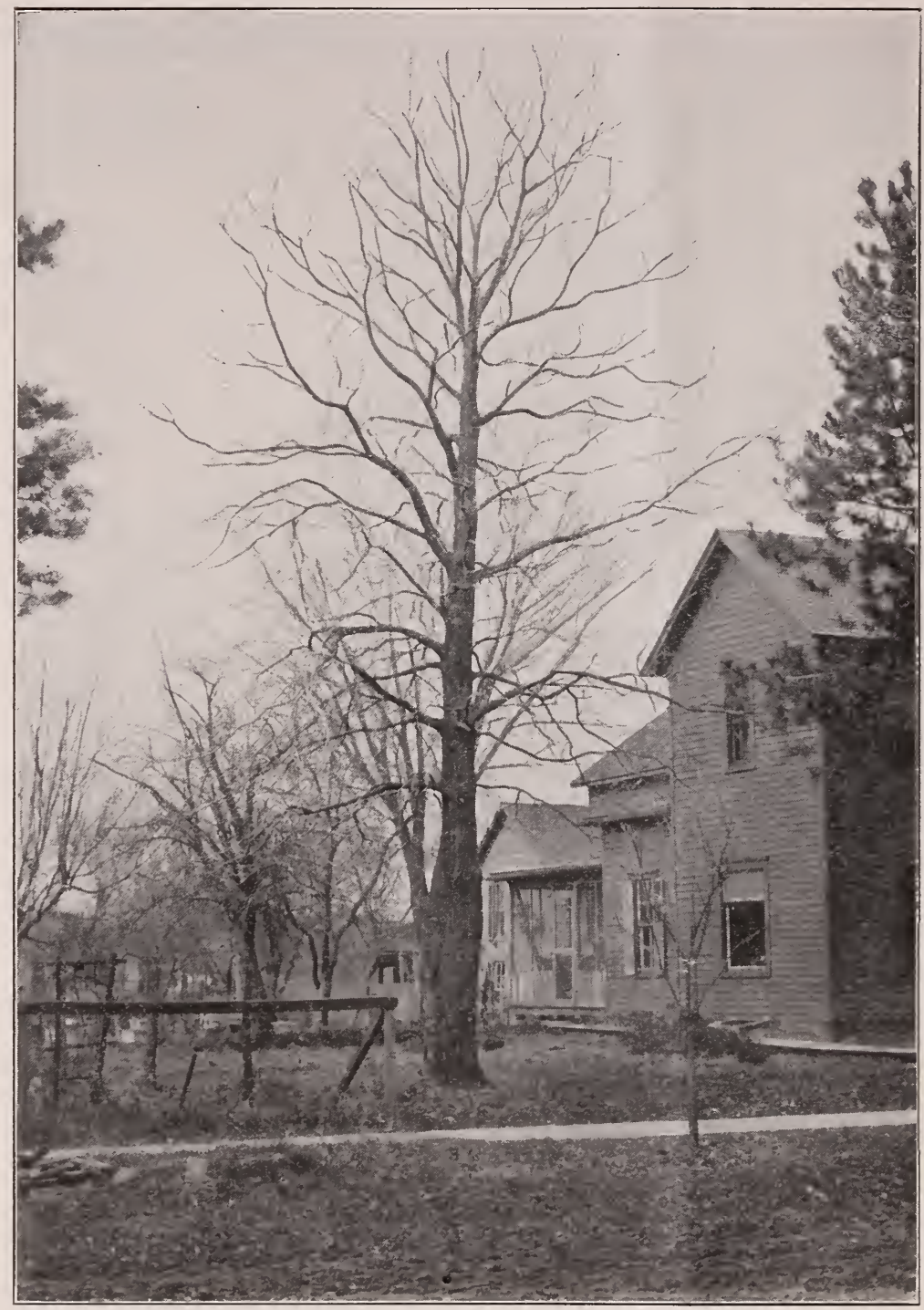

CATALPA SPECIOSA TREE, CRETE, NEBRASKA.

Notice the erect character of the true Catalpa Speciosa. This tree in its native forests grows to the height of 50 to 60 feet, and oftimes attains to a diameter of 3 feet or more.

This very valuable variety has suffered in reputation by the unfortunate behavior of the Catalpa Bignonoides. The Bignonoides is more spreading in its habit of growth, blooms at a different season and should be planted south of the southern line of Kansas. The Catalpa Speciosa, however, is hardy at Davenport, Iowa, and as far west as Denver. See pages 25 and 27 . 


\section{ORNAMENTAL TREES-Con tinued.}

At the St. Louis Exposition Catalpa Speciosa railway ties were shown which had been in use in railroad bed 30 years. The Catalpa has been found to endure in the old frontier stockades and as good gate posts for a very long period. The writer has seen sections of fence rails which had endured 40 years and were still sound.

This tree is one of the easiest of all to transplant. It should be planted freely for the purpose of growing fence posts, telephone poles and railway ties. Perhaps this is the most promising variety of timber for commercial planting in Southern Nebraska.

Price of shade trees on Page 25 and seedlings for timber planting on Page 27.

Elm.-Everyone is familiar with the elm. Its hardihood, its fine spreading branches and above all its durability, make it the most desirable of shade trees. The grand and venerable old elm under whose protecting shade Washington took command of his Continental Army is still standing in Cambridge.

If you wish to plant a tree which shall not only be a source of pleasure to yourself but to future generations, plant the elm. We offer it in sizes to suit everyone.

Trees 4 inches in diameter, $\$ 3.00$ each.

Trees $2 \frac{1}{2}$ to 3 inches in diameter, $\$ 2.00$ each.

Trees 2 inches in diameter, $\$ 1.00$ each.

Nine to ten feet, 50 cents.

Eight to nine feet, 40 cents.

Seven to eight feet, 35 cents.

Six to seven feet, 25 cents.

Box Elder. - Very smosth, thrifty trees. A rapid growing shade tree. Hardy everywhere.

Eight to nine feet, 50 cents.

Seven to eight feet, 35 cents.

Six to seven feet, 25 cents.

Soft Maple. - One of the handsomest of all shade trees, regular in outline, with beautiful leaves. Hardy and rapid in growth. We offer choice, smooth trees well suited to lawn, street or park planting.

Ten to twelve feet, 75 cents.

Nine to ten feet, 50 cents.

Eight to nine feet, 35 cents.

Seven to eight feet, 25 cents.

Six to seven feet, 15 cents.

Catalpa Speciosa.-Do not confuse this with the tender Catalpa Bignonoides. Catalpa Speciosa is hardy as far west as Denver and superior in every way. An erect, rapid growing tree with broad, dark green leaves and beautiful perfunned blossoms. Easy to transplant. Never suffers from bemars or other insect enemies.

Ten to twelve feet, 60 cents.

Nine to ten feet, 50 cents.

Eight to nine feet, 40 cents.

Seven to eight feet, 25 cents.

Linden.-A rapid growing, peautiful tree, with rich green foliage and fragrant flowers. symmetrical in growth. Very choice.

Eight to nine feet, 50 cents.

Seven to eight feet, 40 cents. 


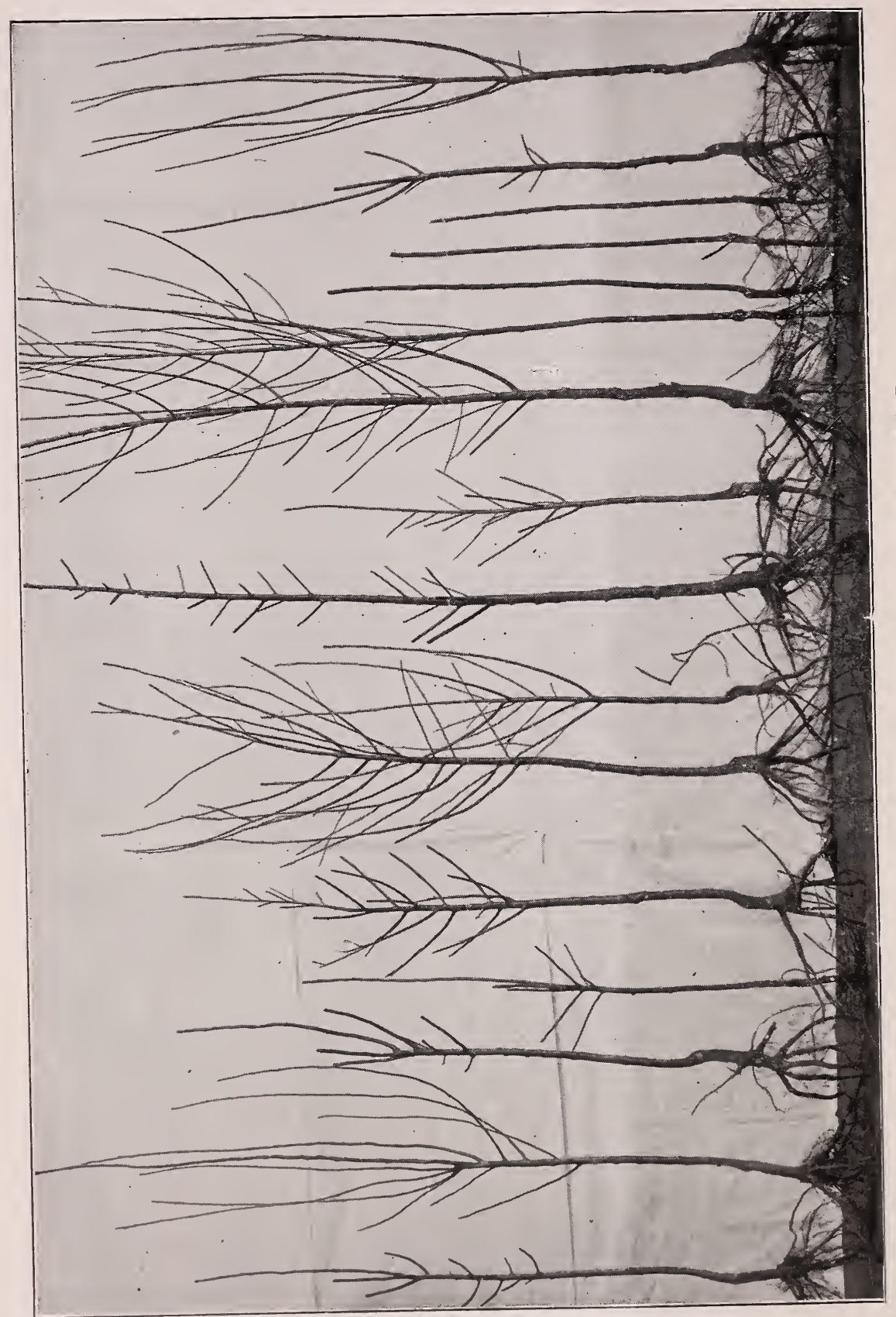

हี

잉

छ छ

ช

ह

छ

İ 0

पे है

द 50

ข

.

ค่

되 엉 ह

纪录

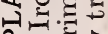

A

埪过

武圾

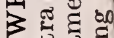

종

되되응

달

造.

드웡

. हี

ค은

世

色

逮资

陆

되류 है

둔

\& 0

잉

되 $N$

क

¿

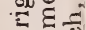

을

$\pm$

可

हृ कृ

[

I $\frac{0}{\mathrm{C}}$

实

3

แั

ํํㅇ

Е 


\section{Frequent Shallow Cultivation Retains Moisture}

\section{ORNAMENTAL TREES-Continued.}

Mt. Ash.-Seven to eight feet, 50 cents.

Six to seven feet, 35 cents.

Ash.-Seven to eight feet, 35 cents.

Six to seven feet, 25 cents.

Thurlow's Weeping Willow. - A fine weeping tree. Long pendant trailing branches with beautiful foliage and grayish green bark. A fine ornamental tree for lawns and cemeteries. Usually sold at $\$ 1.50$ upwards. We make an exceptionally low offer on these.

Eight to nine feet, 50 cents.

Seven to eight feet, 35 cents.

\section{Forest Trees}

\section{STRONG, HEAVY SEEDLINGS}

Black Locust. - United States Forestry Department highly recommends it for timber plantations in Nebraska and Kansas. Should be planted in dry situations to prevent its growing too late and being unripe when winter sets in. Fine for posts.

Eighteen to twenty-four inches, $\$ 1.00$ per $100 ; \$ 5.00$ per 1,000 .

Two to three feet, $\$ 2.00$ per $100 ; \$ 6.00$ per 1,000 .

Elm. - Twelve to eighteen inches, $\$ 1.00$ per $100 ; \$ 5.00$ per 1,000 .

Eighteen to twenty-four inches, $\$ 1.25$ per 100 .

Two to three feet, $\$ 2.50$ per 100 .

Box Elder.-Ten to fifteen inches, 75 cents per $100 ; \$ 4.00$ per 1,000 .

Twelve to eighteen inches, $\$ 1.00$ per $100 ; \$ 5.00$ per 1,000 .

Eighteen to twenty-four inches, $\$ 1.50$ per 100.

Two to three feet, $\$ 3.00$ per 100 .

Three to four feet, $\$ 5.00$ per 100 .

Ash.-Twelve to eighteen inches, 60 cents per $100 ; \$ 4.00$ per 1,000 .

Two year, eighteen to twenty-four inches, $\$ 1.00$ per $100 ; \$ 5.00$ per 1,000 .

Two year, two to three feet, $\$ 2.00$ per 100 ;

Two year, three to four feet, $\$ 4.00$ per 100 .

Russian Mulberry.--Twelve to eighteen inches, $\$ 1.00$ per $100 ; \$ 5.00$ per 1,000 .

Eighteen to twenty-four inches, $\$ 1.50$ per $100 ; \$ 6.00$ per 1,000 .

Osage.--Surromnd your pasture with a hedge. Hardy, durable, equally effective and less dangerous than barbed wire. Grows posts in a few years. Very strong, first-class planis, $\$ 4.00$ per 1,000 .

Cottonwood. - Twelve to eighteen inches, \$1.00 per 100.

Fighteen to twenty-four inches, $\$ 1.25$ per 100.

Three to four feet, $\$ 2.00$ per 100 .

Catalpa Speciosa. - Hardy the length of the state. Grows durable posts quickly.

Twelve to eighteen inches, $\$ 1.00$ per $100 ; \$ 5.00$ per 1,050 .

Eighteen to twenty-four inches, $\$ 1.50$ per $100 ; \$ 10.00$ per 1,000 .

Two to three feet, $\$ 2.50$ per 100 .

"I wish to thank you very much for the extra stock you sent me last year. They were the finest I ever planted, and have done weil,",

Clay County.

MRS. E. E. SILVER. 


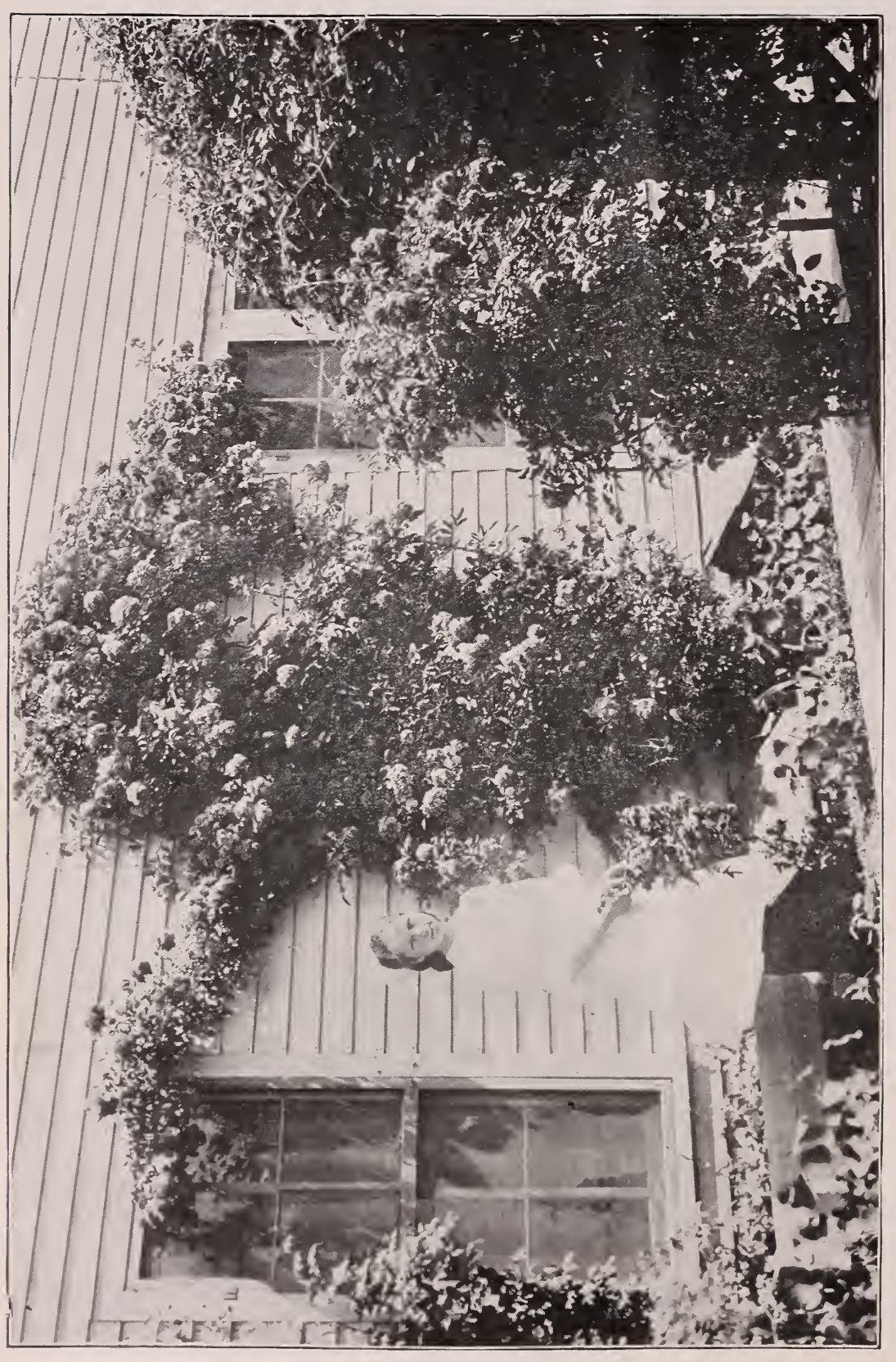

$\circ$

(ㄷ)

뙥

\&

등응

느

뜸

붕

융

보동

$\measuredangle<\frac{\Omega}{0}$

绐

प्र०

요

世出

设宫出

뙹ㅇㄴ운

卷芯。

뜨눙

טo

纪㤩及

田近。

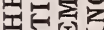

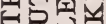

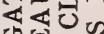

$\checkmark[x) \approx$

次

되민

도의

되오웝

幽

되응 क

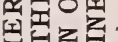

凷는

분정됭

다 $\alpha$ 동

挤成 


\section{Evergreens}

Black Hills Spruce. - Native of the Black Hills of Dakota. Rich, dark green foliage, beautiful the year round and particularly hardy. Thrives in dry situations. Easy to transplant. Very storky trees, heavilw nooted. Sold in dozen and half dozen lots only.

l'welve to fifteen inches, $\$ 4.00 \mathrm{pe}_{2}$ jozen.

Fifteen to eighteen inches, $\$ 5.00$ per dozen.

Eighteen to twenty-four inches, $\$ 6.00$ per dozen.

Special size, two feet, 75 cents; three feet, $\$ 1.00$.

We urge our customers to subscribe for some farm journal. We recommend the following list as useful to western plinter:

WESTERN FRUIT-GROWER, St. Joseph, Mo.

TWENTIETH CENTURY FARMER, Omaha, Neb.

NEBRASKA FARMER, Lincoln, Nebraska.

THE HOSPODAR, (Bohemian) Omaha, Nebraska.

PRAIRIE FARMER, Chicago, Illinois.

ORANGE JUDD FARMER, Chicago, Illinois.

TRIBUNE FARMER, New York City, N. y.

THE APPLE SPECIALIST, Quincy, Illinois.

\section{Roses}

\section{Heavy Two-Year-Old Bushes}

These are very different from the tiny roses sent out from greenhouses which require extreme care. Our roses are all grown in the field where they are cultivated like corn. In this manner they become thoroughly inured to out-door culture.

We send them out as fine, heary, well developed bushes, that often blossom freely the first surnmer.

"I ain very much pleased with the trees received of you as well as plants; particularly fifty hardy roses ordered last year, all of which lived and bloomed splendidly the same season." Seward County.

F. B. TIPTON.

Soil Preparation.-Spade to a depth of twenty inches an area large enough to contain the number of roses or shrubs desired. Mix in fine, old manure thoroughly and make the whole very fine. After planting be sure to maintain a mulch of fine soil by frequent enltivation. Water abındaintly, but underneath the surface. Otherwise the surface will soon bake.

Winter Care.- The roses we offer will stand out over winter and do not require taking up. Protect the roots with ample mulching, using fine, old manure, leaves or hay. It is best to tie up even hardy roses before winter sets in. A little care will render them perfectly safe.

Baltimore Belle.-Pale blush; nearly white. A climber.

Prairie Queen.-Bright pink; very hardy. A climber.

Crimson Rambler.-Deep crimson: Most popular climber grown. Blossoms in clusters of five to twenty-five.

"I beg to acknow!edge receipt of six of the finest peach trees I ever planted."

Saline County.

J. W. SHABATA. 


\section{Special Cheap List of Fruit Trees at Remarkably Low Prices}

The special prices listed below are for trees either not smooth enough or too light to go into either our Extra Select or Select grades.

Everything listed is well rooted. It is as good as any of the stock listed in other cheap catalogues at corresponding prices.

We say frankly this is not the class of stock we use in our own planting nor do we recommend it to you. It is good enough of its kind but our honest opinion is that stock from our Extra Select list will prove by far the cheaper and more satisfactory in the long run.

Apples.-Janet, Missouri Pippin, Maiden Blush, Winesap, Ben Davis and others. 3 to 4 feet, 12 cents each; $\$ 1.25$ per dozen; $\$ 8.00$ per 100 . 4 to 5 feet, 15 cents each; $\$ 1.50$ per dozen; $\$ 10.00$ per 100 .

Crab Apples.-Whitney, Florence and others. 3 to 4 feet, 20 cents each; $\$ 2.00$ per dozen.

Plums.-Sandoz, Wyant, De Soto, Stoddard, Berwood, Profuse, Hawkeye and others. 2 to 3 feet, $\$ 2.50$ per dozen; $\$ 15.00$ per 100 . 3 to 4 eet, $\$ 3.00$ per dozen; $\$ 20.00$ per 100.

\section{PACKING}

The prices annexed include packing and delivering to express or freight office free of charge. All stock will be carefully packed in boxes or bales, save large lots packed in bulk. We guarantee all stock to be packed to reach customers in good order.

\section{CORRESPOND EARL}

before the rush of delivery, remember that it is difficult to answer correspondence as fully as might be desired while packing thousands of orders in the few short weeks of thespring. $\mathrm{We}$ invite anyone who may receive this catalogue to feel perfectly free at all times to write us for information upon such horticultural subjects as they may be interested in.

We may not be able to answer all questions to your entire satisfaction, but you are freely welcome to such knowledge as we possess.

Address all correspondence to

E. F. STEPHENS,

CRETE, NEBRASKA. 